DOI https://doi.org/10.18551/rjoas.2021-01.18

\title{
EFFICIENCY ANALYSIS OF USING PRODUCTION FACTORS IN THE BROILER CHICKEN FARM BUSINESS PARTNERSHIP PATTERN OF KENDAL REGENCY, INDONESIA
}

\author{
Pakpahan Sartika*, Prasetyo Edy, Sunarti Dwi \\ Faculty of Animal Husbandry and Agriculture, University of Diponegoro, Indonesia \\ *E-mail: pakpahansartika24@gmail.com
}

\begin{abstract}
Broiler chicken farming is widely developed in Kendal Regency by using a partnership pattern between the company as the core and the farmer as the plasma. The benefits of a partnership scheme for breeders among others farmers get supplies of livestock production facilities from the core company and ensure the market for livestock business products. This study is aimed to analyze technical efficiency using production factors and income broilers chicken farming in Kendal regency. The research method used survey method. Taking sample applied multistage random sampling method, where Limbangan and Boja were standardized as sample area, and broilers chicken farming partnership scheme at both districts were standardized as sample (respondents). Numbers of sample were 68 respondents taken from population with amount 210 broilers chicken farmers. The data were analyzed by using technical efficiency analysis based on Cobb Douglas model equation and farming income. The result of the study shows that DOC total and feed quantity effect on broilers chicken production. The amount of using production factors DOC, feed, labor, and OVK have been efficient technically while production factors cage area and electricity have not been efficient. The value of income broilers chicken farming to the farmer is $\mathrm{Rp}$ 16.553.651 by-period production at maintenance scale average 4.566 heads. Revenue cost rasio $(\mathrm{R} / \mathrm{C}$ Ratio) as big as 1,11 which means income or profit obtained in the amount of $11 \%$ of production costs incurred.
\end{abstract}

\section{KEY WORDS}

Technical efficiency, income, broilers.

Animal husbandry is one of the sub-sectors that has an important role in economic development. Livestock in Indonesia are mostly people's farms. People's farms need to be encouraged so that their role can be increased. To that end, the Indonesian government has issued a policy regulating the broiler production system through Law No. 22 of 2013. This policy requires large-scale DOC-producing companies to make partnerships with small-scale breeders. Partnership is a business strategy carried out by two parties. The company as the nucleus and the farmer as the plasma, here in after known as the nucleus-plasma pattern with the principles of mutual need, mutual benefit and mutual strengthening based on their respective responsibilities. The company provides livestock production facilities in the form of Day Old Chick (DOC), feed and medicine and buys back production at the contract price. The plasma farmer provides a cage and its equipment and labor, and receives regular guidance from the core regarding management aspects. This is one of the driving forces for breeders to join the partnership in Illahi et al. (2019).

One of the broiler production centers in Indonesia is the province of Jawa Tengah, especially Kendal Regency. This research was conducted in Limbangan and Boja District through having a form of partnership pattern cooperation.

Partnership performance can be seen from the use of inputs and outputs produced. Sumiarsih's research (2018) concluded that the use of inputs greatly affects the production produced. The level of productivity gives an idea of the level of efficiency. This research was conducted with the aim of analyzing the level of technical efficiency and analyzing the income of broiler chicken farming. 


\section{METHODS OF RESEARCH}

The research location was conducted in Limbangan and Boja District, Kendal Regency. The two districts were selected purposively (purposive), namely the location selection based on the consideration of the largest broiler chicken production in Kendal Regency. Data collection at the research location was carried out in February 2020-March 2020. The research was conducted by using a survey method and the sampling was carried out by the multistage random sampling method. The sample in this study was a partnership pattern breeders with 68 respondents from a population of 210 broiler breeders. The data collection method used interviews and observations based on a questionnaire as a research instrument. The survey research questionnaire design is aimed at individuals who are respondents (Singarimbun and Tukiran, 2012). Sources of data used in this study are primary data and secondary data. Primary data is the data which is obtained directly through interviews with predetermined respondents. Secondary data, namely data documents found in BPS, related agencies or agencies and literature supporting the substance of this research.

The data were analyzed by using technical efficiency analysis based on the Cobb Douglas model production function and livestock business income analysis. Technical efficiency is the ability of the farmer to get the maximum output from using a set of inputs.

The analysis of the production function, the Cobb Douglas model is mathematically formulated as follows:

$$
\begin{gathered}
Y i=\beta 0 X 1^{\beta 1} \times 2{ }^{\beta 2} \times 3^{\beta 3} \times 4^{\beta 4} \times 5^{\beta 5} \times 6{ }^{\beta 6} U^{\varepsilon} \\
L n Y=\operatorname{Ln} \beta_{0}+\beta_{1} L n X_{1}+\beta_{2} L n X_{2}+\beta_{3} L n X_{3}+\beta_{4} L n X_{4}+\beta_{5} \operatorname{Ln} X_{5}+\beta_{6} L n X_{6}+U^{\mathrm{e}}
\end{gathered}
$$

Where: $Y=$ Broilers chicken production $(\mathrm{kg}), \mathrm{X}_{1}=$ Chicken seeds $/ \mathrm{DOC}$ (ekor), $\mathrm{X}_{2}=$ Feed (kg), $X_{3}=$ Cage $\left(\mathrm{m}^{2}\right), X_{4}=$ OVAC (gram), $X_{5}=$ Labor (HOK), $X_{6}=$ Electricity $(\mathrm{KWH}), e=$ natural numbers, $u=$ Residual elements (error) , $\beta 1-\beta 6=$ Independent variable regression coefficient.

Income analysis is used to determine the value of broiler chicken business income. The broiler chicken farm income is mathematically formulated as follows:

$$
(\pi)=T R-T C
$$

Where: $\pi=$ livestock business income $(\mathrm{Rp}), \mathrm{TR}=$ total receipts $(\mathrm{Rp}), \mathrm{TC}=$ Total Cost or fixed costs (Rp) (Soekartiwi, 2003). With the decision, if TR> TC, then the broiler chicken farming is able to generate profits. Analysis of broiler chicken business income in Kendal Regency uses the $\mathrm{R} / \mathrm{C}$ ratio (Revenue-Cost ratio) to determine the ratio of profit and cost levels of farming:

$$
\text { R/C Ratio } \frac{\text { Revenue }}{\text { Cost }}
$$

Where: R: Total livestock business revenue (Rp), C: Total livestock business costs $(R p)$, If: $R$ / $C$ ratio $>1$, it can be said that this farming is profitable, while $R / C$ ratio $<1$, it can be said that this farming is detrimental because the costs incurred are greater than the revenue earned.

\section{RESULTS AND DISCUSSION}

Respondent characteristics are used to determine respondents based on gender, education, experience, age, occupation and family dependents. This is expected to provide an overview of the condition of the breeders. 
Table 1 - Characteristics of Broiler Breeders In Kendal Regency

\begin{tabular}{lll}
\hline \hline Respondent character & Respondent & $\%$ \\
\hline Gender & 2 & \\
Female & 66 & 2,95 \\
Male & & 97,05 \\
Education & 14 & 20,59 \\
Elementary School & 17 & 25,00 \\
Junior High School & 29 & 42,64 \\
Senior High School & 1 & 1,48 \\
D3 & 7 & 10,29 \\
S1 & & \\
Experience & 31 & 45,58 \\
5-9 years & 15 & 22,05 \\
10-14 years & 8 & 11,76 \\
15-19 years & 14 & 20,59 \\
$\geq 20$ years & & \\
Age Of Livestock & 63 & 92,64 \\
22-55 years & 5 & 7,36 \\
$\geq 65$ & & 61,76 \\
The Main Job & 42 & 29,41 \\
Breeder & 20 & 2,94 \\
Farmer Breeders & 2 & 5,88 \\
Breeders Trader & 4 & \\
Pekerjaan tambahan & & \\
\hline
\end{tabular}

Based on gender, male breeders were dominated by 97.05 percent and 2.95 percent female because men are more adept at increasing effectiveness and productivity as a trigger for the success of the livestock business.

Based on the education level of the breeders, it is dominated by high school and junior high school of 67.64 percent and the lowest is D1 and S1 of 11.76 percent, choosing a livestock business because the results obtained are more profitable than working as an employee. The level of experience in breeding is dominated by 5-9 years as much as 45.58 percent which is classified as a beginner breeder business which still requires broad insight in the farming business. Based on the age level of the breeders, the age of 22-55 years is dominated by 92.64 and the lowest is $\geq 65$ at 7.36, this is influenced by the level of productive work. Based on the level of work, the focus is dominated as breeders at 61.76 percent and the lowest is breeders as many as 2.94 percent. This is influenced by the level of income earned.

Table 2 - Data Normality Test Of Broiler Chicken Production Factors

\begin{tabular}{|c|c|c|c|c|c|c|c|c|}
\hline & & Production & DOC & Feed & TTK & 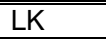 & OVVK & Electricity \\
\hline $\mathrm{N}$ & & 68 & 68 & 68 & 68 & 68 & 68 & 68 \\
\hline Normal Parameters ${ }^{a, b}$ & Mean & 8991.24 & 4551.47 & 14065.99 & 12225.09 & 322.24 & 461 & 237.34 \\
\hline & Std. Dev & 1582.98 & 728.62 & 2662.06 & 1371.85 & 15.94 & 107.24 & 41.64 \\
\hline Most Extreme & Absolute &, 060 &, 161 &, 054 & ,078 &, 115 &, 130 &, 118 \\
\hline Differences & $\begin{array}{l}\text { Positive } \\
\text { Negative }\end{array}$ & $\begin{array}{l}, 060 \\
-, 050\end{array}$ & $\begin{array}{l}, 161 \\
-, 119\end{array}$ & $\begin{array}{l}, 051 \\
-, 054\end{array}$ & $\begin{array}{l}, 078 \\
-, 078\end{array}$ & $\begin{array}{l}, 053 \\
-, 115\end{array}$ & $\begin{array}{l}, 130 \\
-.076\end{array}$ & $\begin{array}{l}, 087 \\
-118\end{array}$ \\
\hline Kolmogrovo-SmirnovZ & & ,494 & 1324 &, 444 &, 643 &, 947 & 1070 &, 974 \\
\hline Asymp. Sig. (2-tailed) & &, 967 &, 060 & ,989 & ,803 & ,331 & ,202 & ,299 \\
\hline
\end{tabular}

Data normality is carried out to see whether the residual value is normally distributed or not. The statistical test which is conducted in this study was the Kolmogorov-Smirnov test. Based on Table 2 shows that the independent and dependent variables are normally distributed. This can be seen from the significance value of all variables greater than 0.05 so it is necessary to do a parametric test. The multicolinearity test is used for multiple regression analysis consisting of two or more independent variables, aiming to determine whether in a multiple linear regression model there is a correlation between variables (Ghozali, 2016). Detection of the presence or absence of multicolinearity in the regression model can be seen from the Variant Inflation Factor (VIF) and tolerance. Regression is free of multicollinearity if the VIF value is $<10$ and the tolerance value is $>0.10$. 
Table 3 - The results of the multicollinearity test of the broiler chicken production factors

\begin{tabular}{lll}
\hline \hline Independent variable & Tolerance & VIF \\
\hline DOC &, 106 & 9,476 \\
Feed &, 179 & 5,595 \\
Tenaga kerja &, 921 & 1,086 \\
Wide Cage &, 507 & 1,972 \\
OVK &, 267 & 3,741 \\
Electricity &, 308 & 3,249 \\
\hline
\end{tabular}

Based on the test results in Table 3, the VIF value for all variables is smaller than 10 , the tolerance value is greater than 0.10 , so it is concluded that there are no symptoms of multicolinearity between the independent variables.

The heteroscedasticity test was carried out by using the scatterplot test. The scatterplot graph of this study looks randomly spread, this shows that heteroscedasticity does not occur in the regression model. The results of the heteroscedasticity test in Figure 1 show that the points are randomly distributed, it can be concluded that there is no heteroscedasticity in the regression model, so the regression model is feasible to use.

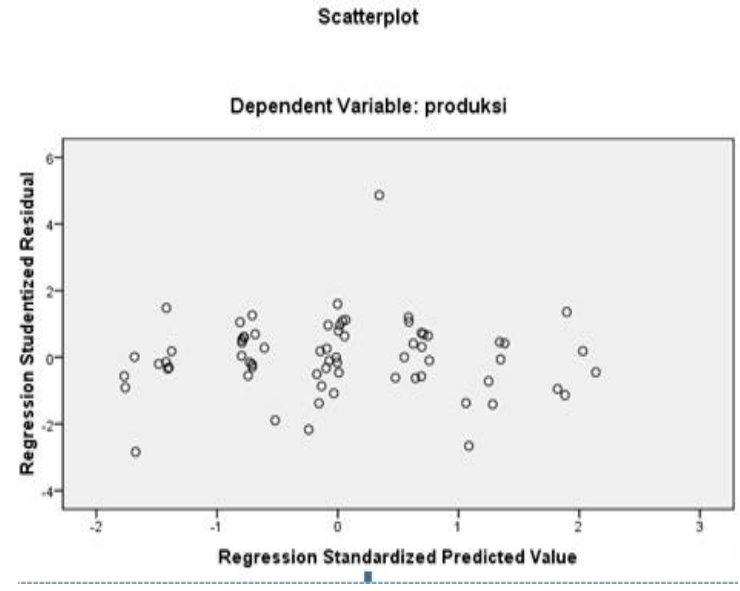

Figure 1 - Scatterplot Graph

The autocoleration test used with the Durbin-Watson test aims to test whether in the linear regression model there is a correlation between the non-independent residual errors from one observation to another (Ghozali, 2011).

Table 4 - Autocorrelation test results

\begin{tabular}{lllll}
\hline \hline DW & du & 4-dua & Explain & Conclusion \\
\hline 2,092 & 1,803 & 2,196 & du $<$ dw $<4$-dua & Autocorrelation free \\
\hline
\end{tabular}

Table 5 - The results of regression analysis of the influence of several factors on broiler production in Kendal Regency

\begin{tabular}{lllll}
\hline \hline Input Variable & Estimated Value & Standard Error & T & Sig \\
\hline Constanta & $-0,769$ & 0,618 & $-1,245$ & 0,218 \\
Doc $\left(\mathrm{X}_{1}\right)$ & 0,735 & 0,083 & 8,806 & 0,000 \\
Feed $\left(\mathrm{X}_{2}\right)$ & 0,343 & 0,052 & 6,604 & 0,000 \\
TK $\left(\mathrm{X}_{3}\right)$ & 0,053 & 0,087 & 0,603 & 0,549 \\
Cage Large $\left(\mathrm{X}_{4}\right)$ & $-0,034$ & 0,027 & $-1,258$ & 0,213 \\
OVK $\left(\mathrm{X}_{5}\right)$ & 0,042 & 0,074 & 0,562 & 0,577 \\
Electricity $\left(\mathrm{X}_{6}\right)$ & $-0,015$ & 0,041 & $-0,374$ & 0,710 \\
\hline F Test & 270.568 & & & \\
F sig & 0,000 & & & \\
R square & 0,964 & & & \\
\hline
\end{tabular}


Based on Table 4 shows the dw value of 2.092 and the dw table value (4-dua) 2,196. So it can be concluded that there is no positive or negative autocorrelation and it meets the requirements for the classical assumption test. After the proposed regression model passes the classical assumption test, it can proceed to hypothesis testing with simultaneous test (F-test), partial test (t-test) and the coefficient of determination (R Square).

The estimation results using the OLS method obtained the calculated $F$ value of 270,568 with a significance probability result of 0,000 , greater than the $F$ table value of 2.25 at the level of $5 \%$. This shows that all the independent variables simultaneously have a significant effect on the dependent variable at the 95 percent confidence level.

The DOC variable turned out to be statistically very significant in influencing the broiler production variable with a $t$ value of 8.806 greater than the table value of 1.670 so that the DOC variable had an effect on broiler production. This means that each one percent increase in DOC from 4566 tails will increase the production of broiler chickens by 0.822 percent. This is because the DOC is kept by the farmer that is provided by the core, and has gone through the selection stage. This is in line with the research of Sunarno et al (2017) that the success of breeding is influenced by the quality of the DOCs being kept. If the quality DOC is maintained, then during maintenance there will be no problems, which mean that the resulting performance depends on environmental influences. Feed parameters turned out to be statistically significant effect on broiler production variables with a significance probability value of 0.000 and have a positive effect. Judging from t count 6.604 greater $t$ table 1.604 , regression coefficient of 0.343 , indicating that there is a positive influence or relationship between the amount of feed and broiler chicken production in Kendal Regency. This means that every one percent increases in feed from $14,066 \mathrm{~kg}$ will increase broiler production by 0.343 percent. The feed used in the maintenance of broiler chickens in Kendal Regency has met nutritional needs and the feeding is in accordance with the recommendations so that it can significantly increase broiler production. Dira et al (2017) stated that feed has a real and positive effect on production.

$\mathrm{R}^{2}$ intended to calculate how much variation of the dependent variable can be explained by the independent variable. The statistical value of the coefficient of determination is 0.964 , meaning that 96.4 percent of the variation in broiler production variables can be explained by the variation of the independent variables intended in the model, while the remaining 4.6 percent is explained by variations from other variables not included in the model. According to Santoso (2000) that for regression with more than two independent variables, adjusted $R_{\text {squared }}$ is used as the coefficient of determination.

Technical efficiency is a combination of the ability of an economic unit to produce maximum output from a number of inputs used. This efficiency is calculated by looking at the ratio of input and output. Technical efficiency is done by calculating the elasticity of production which is known from the regression coefficient.

Table 5 shows the DOC elasticity of 0.735 , which states that it is technically efficient $(0$ $<E p<1$ ), which means that each addition of one percent of the number of DOCs from an average of 4566 chickens will increase the production of broiler chickens 0.735 percent of the average production of 4566 birds. This means that the more seeds used, the broiler production output is thought to increase as well. This is because the quality of the DOC used is good enough so that it can survive maintenance until the finisher phase. This is in line with the journal Wenda et al. (2020) that a good DOC quality will greatly affect the smoothness of the production process. The feed elasticity value of 0.343 indicates that it is technically efficient $(0<\mathrm{Ep}<1)$, which means that every one percent addition of feed from $14066 \mathrm{~kg}$ will increase broiler production by 0.343 percent. It is assumed that the feed consumed by broiler chickens is used in the formation of meat, thus affecting the body weight gain. This is in line with the research of Dira et al (2017) which states that feed has a significant and positive effect on broiler chicken production, influenced by the quantity of feed and environmental factors. If everything interacts well, then the livestock growth being raised will be optimal.The labor elasticity value of 0.035 indicates that it is technically efficient $(0<E p<1)$, which means that every 1 percent addition of labor will increase the production of broiler chickens by 0.035 percent. This is presumably due to differences in livestock patterns and the average number 
of production scales and the number of workers used are different. The elasticity value of the cage area of -0.034 indicates that it is technically inefficient $(\mathrm{Ep}<0)$, meaning that the use of the production factor for the area of the cage tends to reduce production, where an increase in the use of cage area by 1 percent will reduce the production of broiler chickens by 0.034 percent. The average use of the cage area is $461 \mathrm{~m} 2$ / 4566 tails. The area of the cage has exceeded the recommendation, this is in line with the journal Wenda et al (2020) which states that the size of the cage area is not proportional to the number of chickens kept and on average the farmer does not use the divider as a temporary barrier and the chicken harvesting process is not carried out simultaneously. The elasticity value of OVK of 0.042 shows that it is technically efficient $(0<E p<1)$, meaning that every use of OVK production factors tends to increase production, where the addition of 1 percent OVK will increase OVK production by 0.042 percent. This is thought to be giving OVK according to the required dose, because even though the amount is small it has an important function for the growth and health of broiler chickens. The electrical elasticity value of 0.015 indicates that it is technically inefficient $(\mathrm{Ep}<0)$, meaning that the use of electricity production factors tends to reduce production, where an increase in electricity use by 1 percent will reduce the production of broiler chickens by 0.015 percent. It is suspected that the use of electricity was intended to provide the broiler chickens with light at night so they could eat and drink. This is in line with the journal Wenda et al. (2020) which states that the electricity function is used only as a heater during the brooding period and a light during growing to finisher.

Table 6 - Production Costs, Revenue and Production Income For Broiler Chickens in Kendal Regency

\begin{tabular}{lll}
\hline Description & Details (Rp/period) & Percentage (\%/period) \\
\hline Variable Costs & 151.141 .192 & 98.27 \\
DOC & 32.525 .588 & 21.14 \\
Feed & 116.356 .294 & 75.65 \\
OVK & 1.449 .162 & 0.95 \\
LPG & 526.912 & 0.35 \\
Husk & 283.235 & 0.18 \\
Fix Costs & 2.666 .243 & 1.73 \\
Labor & 2.013 .971 & 1.31 \\
Cut back cage & 386.831 & 0.25 \\
Electricity Cost & 265.441 & 0.17 \\
Total & 153.807 .434 & 100 \\
Revenue & 170.361 .085 & \\
Income & 16.553 .651 & \\
Production $(\mathrm{kg})$ & $8.991 \mathrm{~kg}$ & \\
$R / C$ Ratio & 1.11 & \\
\hline
\end{tabular}

Source: Primary Data Processed, 2020.

The calculation of income is inseparable from the capital spent to run a business. Capital issued in the form of investment will affect the scale of the business which has a direct impact on income. The following is a table of production costs, revenue and production income for broiler chickens in Kendal Regency. Production costs are costs incurred for all production processes consisting of fixed costs and variable costs. Fixed costs and variable costs are the entire amount of costs that must be incurred continuously and are fluctuating to support all activities during the production process. Table 6 shows the total production costs incurred in the broiler chicken business of Rp. 153,807,434. The most costs incurred by the cost of feed and DOC. The cost of feed cannot be constant in one part of the price and one type of feed in each production period because the price of raw materials for making feed which has a fluctuating value affects the price of feed. Some breeders have large feed costs because the whole feed that is given is in the form of finished or complete feed in the starter to finisher phase, this is in line with the study by Momongan et al. complete without rations from other feeds.

Revenue is all results obtained from production during a period which can be seen from the number of livestock sold. The revenue earned by breeders is used to cover production 
costs incurred. Table 6 shows the revenue obtained by broiler breeders in Kendal Regency of Rp. 170,361,085 livestock business revenue is the result of efforts to sell the livestock business, while the capital used in the livestock business is not included in it.

Income is the difference between the total amount of livestock business revenue and the total expenditure incurred for production costs. The higher the difference obtained, the higher the profits obtained in the broiler chicken business. Table 6 shows that the income earned in the broiler chicken business in Kendal Regency is Rp. 16,553,651.

The amount of benefits and additional revenue received in every one rupiah that must be spent every time the production process runs is called the $\mathrm{R} / \mathrm{C}$ ratio analysis. If the ratio value $>1$, then a business is said to be efficient and if $R / C<1$ then this business is inefficient, meaning that the farmer experiences a loss. Table 6 shows the R / C ratio of $1.11 \%$, the calculation explains that the broiler chicken farming in Kendal Regency is feasible to be developed and run because it is considered profitable.

\section{CONCLUSION}

The results showed that the total use of DOC, feed, labor and OVK production factors was technically efficient, while the production factors for cage area and electricity were not technically efficient. Based on the income analysis, seen from the $\mathrm{R} / \mathrm{C}$ value of the ratio of production costs of the broiler chicken business, the partnership pattern is 1.11, which means that the profit obtained by the farmer is Rp. 11, - for a total expenditure of Rp. 100 . This means that this broiler chicken business can be run and profitable.

Suggestions given in this study are to increase broiler chicken business income, breeders must increase business production by managing production factors. In order to achieve the level of technical efficiency and optimal profit, a factor needs to be added, namely DOC and the production factor that needs to be reduced is feed.

\section{REFERENCES}

1. Dedeh Rita Sumiarsih.(2018). Analisis Efisiensi Peternakan Ayama Ras Pedaging Pola Kemitraan and Pola Mandiri di Kecamatan Larangan Kabupaten Pamekasan. Tesis. Universitas Madura. Madura. Tidak dipublikasikan.

2. Paramita A, Kusnadi $\mathrm{N}$ and Harianto. (2017).Efisiensi Teknis Ayam Broile Pola Kemitraan Di Kabupaten Limapuluh Kota. Jurnal Agribisnis Indonesia. 5(1): 1-10.

3. Fadilah R.(2004). Kunci Sukses Beternak Ayam Broiler di Daerah Tropis. Agromedia Pustaka, Depok.

4. Ghozali, Imam.(2013). Aplikasi Analisis Multivariate dengan Program IBM SPSS 21 Update PLS Regresi. Semarang: Badan Penerbit Universitas Diponegoro.

5. Ghozali, Imam. (2016). Aplikasi Analisis Multivariete Dengan Program IBM SPSS 23 (Edisi 8). Cetakan ke VIII. Semarang: Badan Penerbit Universitas Diponegoro, Semarang.

6. Momongan,M.,Massie,T.,Pangemanan,P., Pnadey,J and Oroh N,S.(2020). Analisis pendapatan peternak ayam broiler Pola Kemitraan Kecamatan Mandolang. Jurnal EMBA. 8(2):1-8.

7. Mulyantini.(2010). Ilmu Manajemen Ternak Unggas. Gadjah Mada University Press.

8. Priyatno Dwi. (2009). Mandiri Belajar SPSS. Mediakom. Yogyakarta.

9. Illahi, A., Novita, I danMasitoh,S.(2019). Analisis Pendapatan Peternakan Ayam Broiler Pola Kemitraan Di Kecamatan Nanggung Kabupaten Bogor.jurnal Agribisains.5:2.

10. Santoso, S, 2000, Buku Latihan SPSS Statistik Parametrik, Jakarta: PT. Elex Media Komputindo, Kelompok Gramedia.

11. Sunarno, Rahayu,S and Purnomo, H. (2017). Faktor-Faktor Yang Mempengaruhi Produksi Ayam Broiler Di Kabupaten Wonogiri. Tesis (S2). Universitas Sebelas Maret.

12. Singarimbun, Sofian Effendi and Tukiran. (2012). Metode Penelitian Survai. LP3ES.

13. Wenda W., Widodo A.P.E., Baaka A., Iyai D.A. (2020). Pendugaan efisiensi teknis and faktor-faktor produksi yang mempengaruhi produksi broiler di Kabupaten Manokowari. Jurnal peternakan Indonesia. JPI vol 22 (3):321-331. 